\title{
Redevelopment of squatting housing in Turkey in the case of Altındağ, Ankara
}

\author{
Sinan Akyüz*[0
}

\begin{abstract}
The focus of this paper is the redevelopment of the squatter settlements in Ankara Turkey. Most of the articles focus on gentrification and changing neighbourhood social structures but the redevelopment of the squatter settlements also aims the production of formal low-income housing as well as the integration of previous nonformal housing into formal urban space. Therefore, this article suggests that the contemporary redevelopment project of squatters in Ankara, Turkey is a part of a broader strategy of integrating low-income into the formal housing system by cooperating with a part of low-income groups. The research was made in Altındağ, Ankara by using a deep semi-structured interview, and document analyses method. The researcher conducted 25 interviews with residents and 2 interviews with officials.
\end{abstract}

Keywords: redevelopment, informal housing, housing, rescaling state, squatting housing

\section{Background Information}

In Turkish, the word "gecekondu" literally means 'built overnight' but the term has different meanings in different disciplines (Akbulut and Başlik, 2011). For the purpose of this paper, gecekondu will be used in the context of urban studies in Turkey, where the phenomenon involves housing units that are built on public or private land without any legal title and do not meet construction and zoning rules (Keleş, 2014).

The scale of the rebuilding of Turkish cities over the last two decades has been extraordinary. In 2005, around $30 \%$ of the urban population of the big cities of Turkey were still living in squatter settlements (Ankara Metropolitan Municipality, 2005). Since then the production of the built environment and especially of housing has increased dramatically, from 202,000 dwellings in 2003 to 1,000,000 dwellings in 2016 (TUIK, 2016). In terms of total floor area, the production of housing increased from 45 million $\mathrm{m}^{2}$ in 2003 to 205 million $\mathrm{m}^{2}$ in 2016 (TUIK, 2016). The Ministry of Urbanization and Environment estimates that 6-7 million buildings out of 19 million buildings in Turkey - around $37 \%$ of the existing building stock - need to be rebuilt or reinforced due to earthquake risk. The approximate cost of redevelopment projects for the next 20 years is to reach $\$ 400$ billion (Hurriyet, 2011). 


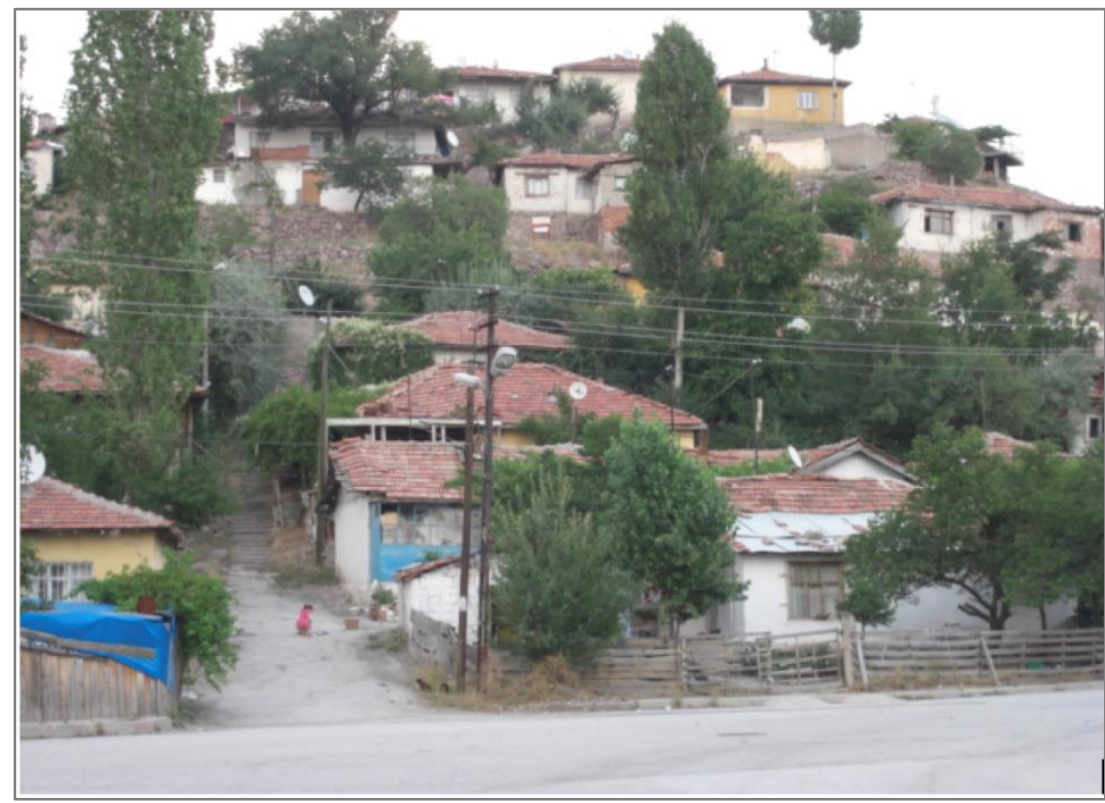

Figure 1 Gecekondus and gardens before the demolition in Baspinar neighbourhood. Sinan Akyuz (2016)

The redevelopment programs in Turkish cities have radically changed not only in the built environment but have also been associated with equally large changes to their economies, their forms of housing, and their social life. Therefore, a comprehensive theorization of housing and wider urban changes, and the role of capital, the state and the low-income groups in these changes was needed. The number and scale of redevelopment projects in the city are very high: the current projects are aiming to reconstruct $40 \%$ of the existing city (Akyuz, 2019). The construction of new low-income housing has been and is a major part of these projects. Therefore, it is inaccurate to explain state intervention in squatter areas entirely in terms of gentrification or total displacement.

\section{Theoretical Background- The Rescaling of the State in Relation to Low-income housing}

\subsection{Re-scaling of state intervention to the Built Environment}

The rescaling state debate is an academic by-product of the interest in globalisation and the changes it brought, yet the literature about rescaling continues to grow and provides important theoretical background for current work on urban and regional politics, especially in relation to the local development (Cox, 2009).

\subsubsection{Strategic Relational approach}

Brenner (2004) sets out a theoretical framework for understanding scales of the state based on the strategic relational approach to the state. On this basis, he analyses the rescaling from national to sub-national levels in Western Europe in the period since the 1970s. Since the early 1970s, state activities targeting the regulation of capitalist urbanisation have been an essential mechanism of the geographical and institutional transformation of the national state. But this does not 'imply the erosion, withering or demise' of the nation-state (Brenner, 2004, p. 2). Unlike claims of a decline in state power and an 'erosion of state territoriality' with the intensification of globalisation, Brenner suggests that 'qualitatively new institutions and regulatory forms are currently being produced at both sub- and supranational scales; and, the role of the national scale as a level of governance is itself being radically redefined in response to the current round of capitalist globalisation' (Brenner 1999, p.439). National economic policies for local and regional development do not have a fixed institutional framework; rather, they have been enabled by, 'a fundamental transformation of state scalar configurations.' Brenner suggests that the city region became, 'the key institutional site in which a major rescaling of national state power has been unfolding' (Brenner 2004, p.3). 
The geographical arrangements of strategic selectivity are explained with the idea of 'hollowing out' of state power. According to Jessop (1990), this power displacement has been happening in three dimensions. The first one is the upward movement of power towards international state bodies since they begin to have greater function and responsibility compared to the Keynesian period. Secondly, a downward movement in which local states became stronger and more active in terms of economic regeneration. Finally, the power started to move outwards with new international networks of local and regional states (Jones, 1997). Being an essential feature of the transition from Fordism to post-Fordism (or in Jessop's terminology, the Keynesian Welfare State to the Schumpeterian Workfare State), the 'hollowing out' process also involves changes in state spatial relationships.

Following Jessop, Brenner (2004) suggests a process of state downscaling, resulting in an increase in the roles and tasks of local and regional administrative systems, and restructuring of local and regional institutional configurations. Throughout the EU and North America, state rescaling appeared as neo-liberal restructuring of the economy, aiming to support sub-national growth poles (Brenner 2004;1999). However, the role of the national state in terms of formulation, implementation and coordination of urban policies is still important (Brenner, 2004).

Cox (2009) suggests that Brenner's arguments concerning state rescaling are problematic in two respects when applied to the US. Firstly, Brenner argues that the territorial rescaling of the state to achieve and maintain economic growth is an outcome of top-down forces. However, Cox emphasises bottom-up forces in the case of US cities. Secondly, Brenner focuses on the supply-side, 'urban locational policies', but in the US example, Cox suggests the driving force is not building up local productive capacity but redistribution of national investment. States and local governments compete with each other for more investment, such as airports, highways, prisons and central government agencies. Cox emphasises the importance of competition between regions and between localities, arguing that this is reflected in regional secessionist movements in Europe.

\subsection{Re-scaling of state intervention to the Built Environment in Turkey}

After the 1980s, there has been a radical reordering in the finance and service sectors and further concentration of production in the big cities of Turkey, which leads to an increase of formal and professional workers living in cities as well as overall population growth in cities. These changes required massive restructuring of cities including new public transport systems. This was accomplished through setting up the Metropolitan Municipalities and through interventions by the national government; only these bodies had the large resources and the territorial sweep necessary for city restructuring.

Secondly, governments since the 1990s have sought to end gecekondu living and transform houses of the low-income to formal, capitalist-built housing. This is seen as providing a materially higher standard of living and also providing large contracts for large construction companies. The programmes to build new low-income housing have required a major input from the Mass Housing Agency (MHA), from the Metropolitan Municipalities, as well as some roles for District Municipalities. Again, the enormous scale of the redevelopment of the gecekondus has required higher spatial scales of the state to lead the programmes. The District Municipalities did not have the resources, legal powers or expertise. Therefore, especially after 2002 central state agencies and metropolitan municipalities gained further legal power and economic power in order to implement these bigger scale projects. Whilst the district municipalities did not become irrelevant, there has been an overall shift in power upwards (Section 2.1). Moreover, the MHA made the national state an essential actor in housing production, which is also an upwards movement of power. Note that the wholesale restructuring of cities and low-income housing in Turkey in the last thirty years has no parallel in the More Developed Countries (MDCs). Therefore, state rescaling has been very different in Turkey from the MDCs. 
The state scalar change has also been powered by the Justice and Development Party (JDP) government's project to change class relations. We noted that new local policies and interventions may not be only class-disciplinary but may also be class-cooperative and that these class relations may extend across both production and reproduction spheres. This combination of class relations within local politics has been the case in Turkey. Gecekondu housing is outside of normal capitalist relations of land ownership and building. The elimination of the gecekondus was partly aimed at subjecting low-income residents to the rule of money and law (Clarke, 1991; Das, 2006). Since the 1980s, workers in employment have been subjected to greatly increased disciplinary power of capital and the state. The JDP, however, sought to legitimize its rule with at least a portion of the urban low-income by providing a higher material standard of housing combined with new social and cultural facilities in the neighbourhoods, based partly on Islamic notions of charity. At the same time, the demolition of the gecekondus destroyed strongly collective aspects of social life, and the new housing has tended to privatise and isolate residents from each other, thus serving neoliberal ends.

\subsubsection{Mass Housing Agency (MHA)}

One of the main tools for upscaling of state intervention to the Built Environment in Turkey is Mass Housing Agency. The MHA has gained and increased its power in relation to different duties after 2002. Firstly, the MHA gained the power to establish companies and become a partner of existing companies in relation to housing production. This housing production power can also be used in relation to squatter redevelopment and the prevention of squatter areas, or to restore historical and regional architecture. Secondly, the MHA gained the power to undertake profitseeking projects similar to the private sector. Third, the MHA was given the power to prepare plans at all scales and change existing plans relating to mass housing development. Moreover, this power also includes the ability to compulsorily purchase land and property to enable mass housing production. Finally, all duties and powers of the Urban Land Office and the Real Estate Bank, along with 64.5 million $\mathrm{m}^{2}$ of land, was transferred to the MHA in order to integrate housing production, land acquisition and redevelopment (Gündoğdu and Gough, 2009; Yılmaz, 2016; Geray 2007). The $\mathrm{MHA}$, therefore, can prepare and confirm new land-use planning for all private and public land in Turkey.

With this strong institutional power, the MHA can bypass all conventional regulations, other institutions and plans, and create local bodies operating like private companies (YIlmaz, 2016; Batuman, 2013a; Elicin, 2014). This has given rise to a situation whereby public land has been used for private housing production. The MHA also has the authority to solve all kinds of technical details about any kind of construction and can act as a housing credit (mortgage) provider. This has seen the regeneration strategy of MHA become the principal planning tool of the central government in creating attractive urban space for the investment of national and international capital (Elicin, 2014; Güzey, 2009).

The Improvement and Development Plans (IDP) areas do not have adequate social facilities and infrastructure and have a low quality of urban space. A new strategy for redevelopment came onto the agenda in the 2000s Urban Transformation Plans (UTP). The aim of the UTP is neighbourhood level redevelopment rather than the parcel level approach seen in the IDP projects (Dündar, 2001). Ankara Greater Municipality implemented UTP projects which were aimed to redevelop inner-city gecekondu areas into upper-class housing and office districts (Dündar, 2001). During the 2000s UTP became the main strategy of Metropolitan Municipalities in order to intervene in urban space, especially in gecekondu areas. With the new legal framework in the 2000s different state institutions, including the MHA gained the power to implement redevelopment projects as a part of a disaster prevention strategy. In this way redevelopment of squatter, neighbourhoods were legitimised via an earthquake risk reduction strategy; however, the implementation saw the displacement of the population and urban rent transfer to the private sector (Elicin, 2014). 
With Article 9 of the Urban Transformation Act 2012, urban transformation projects became a nationwide strategy. The MHA becomes the highest planning authority, overall existing acts and regulations. In other words, if there are any legal obstacles to the implementation of redevelopment projects, the MHA Transformation Act has precedence over all existing acts (Elicin, 2014). In short, with the Disaster Risk Act in 2012 central government gained more powerful tools for implementing large scale redevelopment projects and bypassing all existing acts and policies.

With this administrative and economic power, production of 805,072 housing units in 81 provinces of Turkey has been started at 3,517 construction sites since 2002, and a total of 685,533 housing units have been produced since 2002 by only MHA (MHA, 2017). Moreover, 17\% of the total production (135,364 units) is gecekondu redevelopment, and $14 \%$ of total production $(110,107$ units) is for upper-income groups.

\subsubsection{Metropolitan Municipalities}

At the beginning of the JDP period, the trend of the 1990s continued and the power and revenue of the metropolitan municipalities increased; the boundaries of municipalities were expanded and the number increased. These changes have been legitimised with similar reasoning to the 1980s: making the big cities centres of economic attraction at the international level, providing effective and sufficient services. The revenues and duties of metropolitan municipalities (Act 3030, 1984) increased in 2005 (the new Metropolitan Municipality Law No. 5216). Whilst detailed analysis of the legislation is beyond the scope of this chapter it is important to note that there have been major changes to this act: in 2008 with act 5747 and in 2012 with act no. 6360. In relation to the focus of the study, in 2008 metropolitan municipalities gained the power to prepare and implement urban redevelopment projects at all scales, bypassing the district level of municipalities (Bayırbağ and Penpecioğlu, 2015).

Another change in relation to metropolitan municipalities' power over the production of space was the 5366 'the Regeneration Sites Bill' which was enacted in 2005. Ankara Metropolitan Municipality has used this act as the legal basis for its intervention in gecekondu neighbourhoods, article 73 of this act gives municipalities,

'the opportunity to consider all locations, of all characteristics and almost all sizes, as regeneration sites for the purposes of rebuilding and restoring those worn-out urban sections, in line with the development of the city; they may create housing areas, industrial and commercial areas, technology parks and take precautions against earthquakes, or preserve a city's historical and cultural fabric (Güzey, 2009, p. 30)'.

Although the JDP government supported the increase in the revenues and responsibilities of metropolitan municipalities until 2010, the central government became more active after 2010. Central government agencies such as the MHA and the Ministry of Transport, Maritime Affairs and Communications have become more active as agencies of the central government. With increasing power, the MHA became more active in all parts of Turkey and established partnerships with municipalities. Güzey (2016) states that between 2003 and 2015 the MHA prepared 336 redevelopment projects, which set targets to produce 276,162 housing units in partnership with municipalities in different regions of Turkey.

\section{The Redevelopment Process in Altindağ Case}

\subsection{Case Study Area and the Method of the Research}

Altindag is the oldest district of Ankara, with a population of around 365 thousand and an area of 15,847 hectares. The first gecekondu neighbourhoods in Ankara were built here. In 1971 Altindag had the highest percentage of gecekondu residents in Ankara with $49 \%$ of its population living in gecekondus (Kongar, 1973). For decades, Altındağ continued to have the highest number of gecekondu, being 25th in the list of the world's 30 mega slums, with around 400,000 people living in slums (Davis, 2007, p. 27). In 2004, only $30 \%$ of built-up areas were formally constructed. Since 
2004, however, new zoning plans have been prepared, this is an ongoing process and not all the zoning and development plans have been implemented yet. Nevertheless, between 2004 and 2016 the number of formally constructed buildings increased from 30 to $62 \%$ per cent. The Başpınar and Alemdağ neighbourhoods were chosen as case study areas for the research, due to the ongoing process of Improvement and Development (IDP) model projects.

Due to the lack of adequate reports and official documents semi-structured was used as a research method. The researcher conducted 25 interviews with residents and 2 interviews with officials. The researcher interviewed 20 men and 5 women, comprising 22 gecekondu owners and three tenants. The interviews were conducted between March 2015 and June 2016 with 2 different field visits, each lasting 5 weeks.

\subsection{Redevelopment Plans}

Improvement and Development Plans were a national state intervention in order to facilitate redevelopment of informal housing support construction capital and state to provide better housing to the low-income groups. The tools of this intervention were new legal frameworks for city-wide IDPs. This was an upscaling of state intervention. Moreover, this strategy was based on the neoliberal framework of the 1980s, with a market-oriented framework, clear private ownership rights and further strengthening of the relationship between land titling programs.

In order to open the channels for investment in the built environment, municipalities firstly provide the conditions of clear land ownership and zoning. The first IDP plans were prepared in 1984 in Ankara; however, the first IDP improvement and development plans in 1984 did not cover many areas in Altindag. The IDP and legalisation of gecekondus increased the construction of gecekondus in Altindag because it increased people's expectations of legalisation in the future. Therefore, many gecekondu were built after 1984 (Koksal, 2012; Altındağ Belediyesi, 2014). According to the municipality, the construction rights established in 1989 for IDPs were not enough for redevelopment and did not cover all gecekondu areas. Therefore, it did not change the zoning in case study neighbourhoods. The municipality made revision plans in 2007, which increased construction rights in the area. While the first IDP allowed the building of only 1-2 storey houses in the area, after the IDP revision 4-6 storey apartments could be built. In this way, the area became attractive to private developers. By changing zoning, the district municipalities make the area profitable for private developers.

Build-and-sell type housing production is based on agreements between different groups. The actors of these agreements are homebuyers, gecekondu owners after amnesty laws, private developers, small builders, local politicians and city administrators. A private developer starts the production by signing an agreement with each individual landowner in the parcel by offering 30-50 $\%$ per cent of the finished apartment units or money for their plots. Due to increasing construction rights, the land of the gecekondu is much more valuable than the gecekondu itself. Therefore, redevelopment became profitable for gecekondu owners too. Based on this agreement the developers pay gecekondu owners not money but flats. After the agreement, the construction process starts.

In the case of the case study area, 22.7 hectares of the site were previously part of the gecekondu preservation zone, these areas have been conducive to the housing development by the Ministry of Resettlement and Housing in order to prevent the construction of gecekondus. Due to the gecekondu Act No: 775 it was not possible to include these areas as a part of the redevelopment project by the district municipality. In order to overcome this problem, the municipality used the administrative power of MHA, which can intervene in urban space above all existing acts (Section 2.1.1). After the land was transferred to MHA, the areas were bought from MHA by the municipality and sold to gecekondu residents in the neighbourhood, in total 1383 gecekondu residents bought their houses from the municipality through this model (Altindag Belediyesi 2016; Koksal 2012). 
Despite the plans being prepared in 2007, construction was ongoing in 2016. The fragmented ownership of the plots meant it was not possible to reach an agreement between gecekondu owners, making the redevelopment a long process of negotiation. The long negotiation process created clashes between the neighbours. In many cases, the landowners could not reach an agreement because they wanted to maximise their returns. Therefore, many features of the new flats became negotiation points between developers and landowners. Since some of the owners wanted to join the redevelopment and others wanted to wait, conflict ensued. These were not violent conflicts, but they destroyed the solidarity in the neighbourhoods; for example, Resident 1 indicated that he sold land to the developer and bought another flat, $150 \mathrm{~m}$ from his previous house because the neighbours could not reach an agreement. Every feature of the house is a point of negotiation: 'the orientation of the house, the floor area of the house. Since these houses are their biggest investment and, in many cases, their biggest asset, they want to maximise their return.

Due to the long period of construction and negotiations municipalities apply for designation as a disaster risk area. The Disaster Act (2012) aims to overcome these delays and blockages in the redevelopment since the construction of new flats takes a minimum of 1.5 to 2 years. The rent subsidies provided by the Minister of Urbanisation speed up the agreements. The rent subsidy is paid by the Ministry of Urbanisation for 18 months and in 2016 it was 750 Turkish Lira. Therefore, many gecekondu owners made the agreement and apply for rent subsidies under the Disaster Act (2012). If they get the rent subsidies they have to vacate the house. If the gecekondu is officially designated as a disaster risk, the water and electricity service provision stops. Moreover, the Disaster Act also enhances the position of developers and pro-redevelopment shareholders. Based on the Disaster Act, a 2/3 majority is enough for the redevelopment of any building or parcel. If any area, neighbourhood or building is declared as an Area under Disaster Risk, 2/3 of shareholders consensus is enough for starting redevelopment. The general consensus in the neighbourhood is that after the Disaster Risk Act (2012) construction speeded up. This was an upscaling of the state intervention to the build environment in order to speed up the redevelopment (Section 2.2).

\subsection{A Chaotic Construction Site}

Due to this long negotiation process and the land's complex legal status, the redevelopment has been going on for 10 years. In the Alemdag neighbourhood, the construction mostly finished around 4-5 years ago. In the Baspinar neighbourhood, however, the municipality had to follow a different legal procedure, because a big part of the neighbourhood was a gecekondu prevention zone. In the Baspinar neighbourhood, much construction was ongoing. Lack of agreement between different actors turns all neighbourhoods into construction zones. As Resident 5 illustrates, 'I am 24 years old now when I was a kid people were talking about redevelopment projects. Yet, we still live in gecekondu. We want to make some investment in the house, such as a new roof and PVC windows, but we could not because of redevelopment. It does not make sense to make any investment now of course.

Since the entire neighbourhood became like a construction site (Figure 2), it creates security concerns for the residents. In many street constructions continue, therefore the infrastructure such as street lights are not fully functional. The half-demolished gecekondus create security problems (Figure 2); substance abusers occupy the buildings at night. Since many gecekondus have been demolished, the self-policing nature of gecekondu neighbourhoods has disappeared. Therefore, it creates a transition between informality and illegality. Many interviewees suggested that drug selling became a problem in the neighbourhood.

Additionally, people throw more rubbish in the streets so that all neighbourhoods become like a scrap heap, a problem exacerbated by the remains of the demolished gecekondu and ongoing construction. This creates further problems, such as the rats that come out of demolished buildings. 


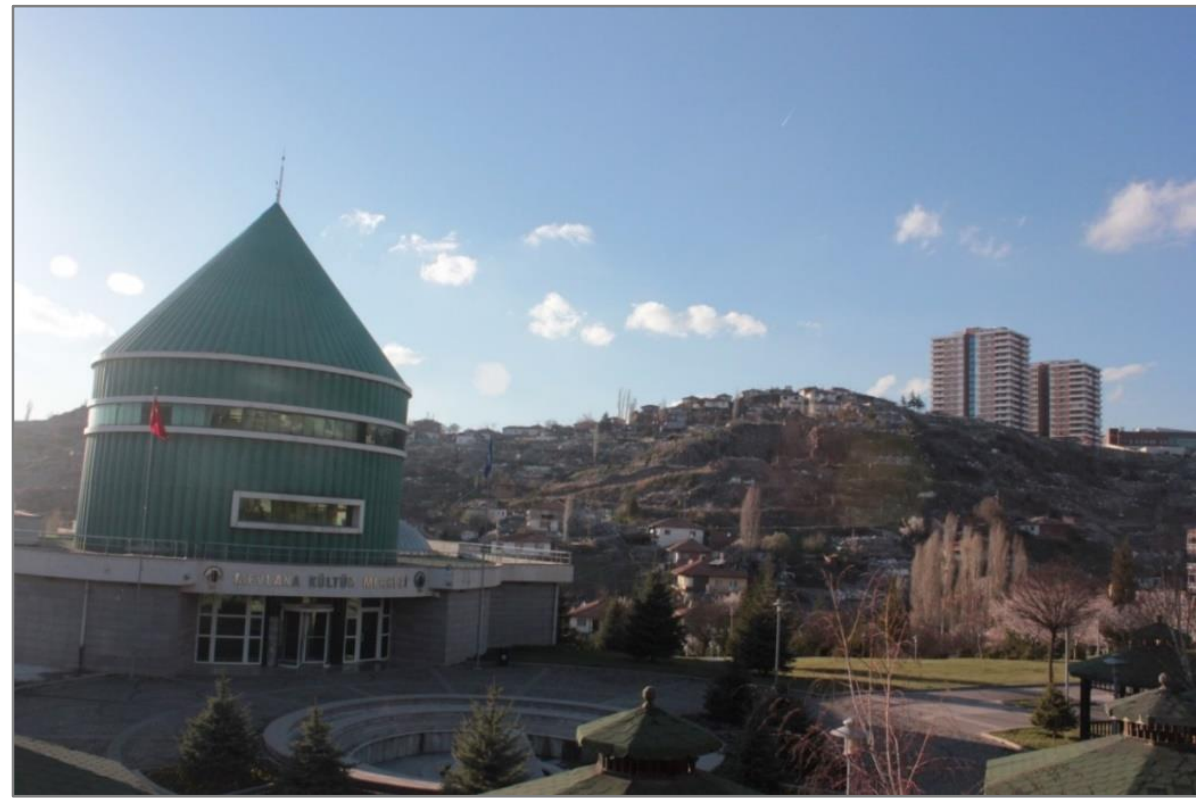

Figure 2 Demolished Gecekondus in the Baspinar Neighbourhoods in the distance, on the hillside. Sinan Akyuz, 2016

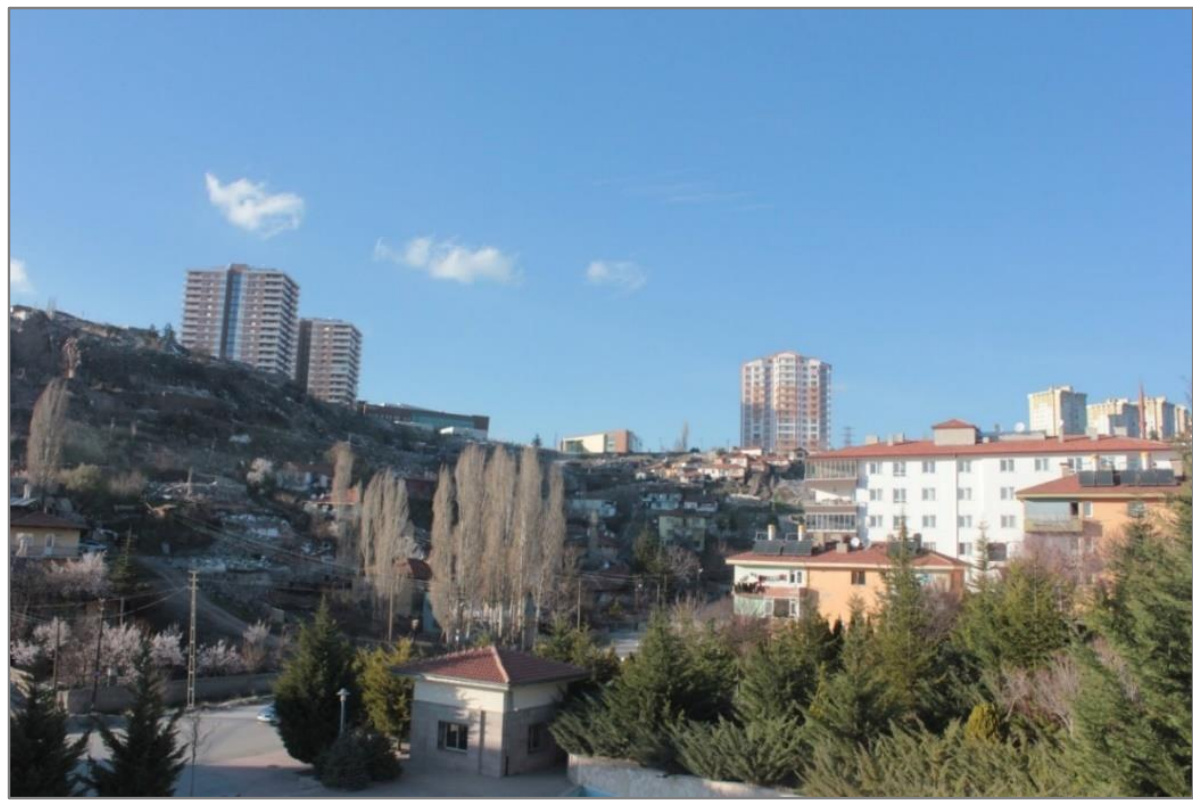

Figure 3 Partly demolished gecekondus and newly constructed apartments next to each other. Sinan Akyuz, 2016

Finally, existing gecekondus and even the demolished gecekondus are occupied by the recent rural-urban migrants. This creates social conflicts between the old gecekondu population and the new renters and squatters. The more some of the recent migrants collect recycling materials and store them in the gardens of gecekondus. This further increase the conflicts, since gecekondu owners think their attitudes make the area less safe. The informal nature of the reconstruction zones makes the area convenient for all kinds of informality and illegalities. All of these create neighbour pressure to reach an agreement with developers and finish the reconstruction as soon as possible.

\section{Gains and loses of residents}

\subsection{Improvement of Living Conditions}

We noted in section 2.1 that new local policies and interventions may not be only classdisciplinary but may also be class-cooperative and that these class relations may extend across the 
spheres of both production and reproduction. This combination of class relations within local politics has been the case in Turkey. Since the 1980s, workers in employment have been subjected to a greatly increased disciplinary power of capital and the state. The governments since 2000 have cooperated with at least a portion of the urban working class by providing a higher material standard of housing combined with new social and cultural facilities in the neighbourhoods. In terms of improved living conditions two main points come with the redevelopment. The first point is the improved living conditions offered by the flats; the second point is the increased public and private investment in neighbourhoods and, therefore, increased economic and social facilities and services.

As many participants suggested, the many basic construction problems with gecekondus, such as leaking roofs, bad plastering, rotten wood, are not problems in the flats. As interviewee 10 said, 'I live in the flat for 4-5 years. I am much more comfortable than before, I don't have the problems of a leaking roof, coal stove, repairing the floor, the garden wall; repairs are not my problem anymore. The infrastructure here is properly underground and it is safer and durable.' In the hometown association, the general idea was that the flats are much more comfortable than the gecekondus. The standard of living is much better in the flats than in gecekondus. Therefore, there is opposition to or conflict against the redevelopment project itself.

All women participants highlighted the advantages of the flats. The coal stove was the biggest problem for the women because their husbands did not help them in its preparation. The women had to clean the oven, set the fire and bring the coal. There was always much work in gecekondu done by women. Therefore, the women that I had a chance to talk to about the gecekondu houses were waiting for the redevelopment and wanted to have new flats. Moreover, the services such as the women's centre became an important part of social life after the redevelopment.

A municipal service, the women's social centre opened in 2008 (Figure 4). The women's social centre in Baspinar Neighbourhood has 1650 members and opens every weekday from 8-5. The provision includes a gym with a fitness teacher, kindergarten and 19 different courses, such as theatre, drama, public speaking and entrepreneurship. The courses open based on demand, so there is no limit to the number of courses that could be run. There is also a theatre group established by women who joined the drama courses at the centre. The cooking classes and competitions are one of the most popular activities. There are also seminars about drug addiction and women's health. There are illiterate women in the neighbourhood; therefore, the municipality also gives writing and reading classes in the centre (Official 1, 11.03.2016).

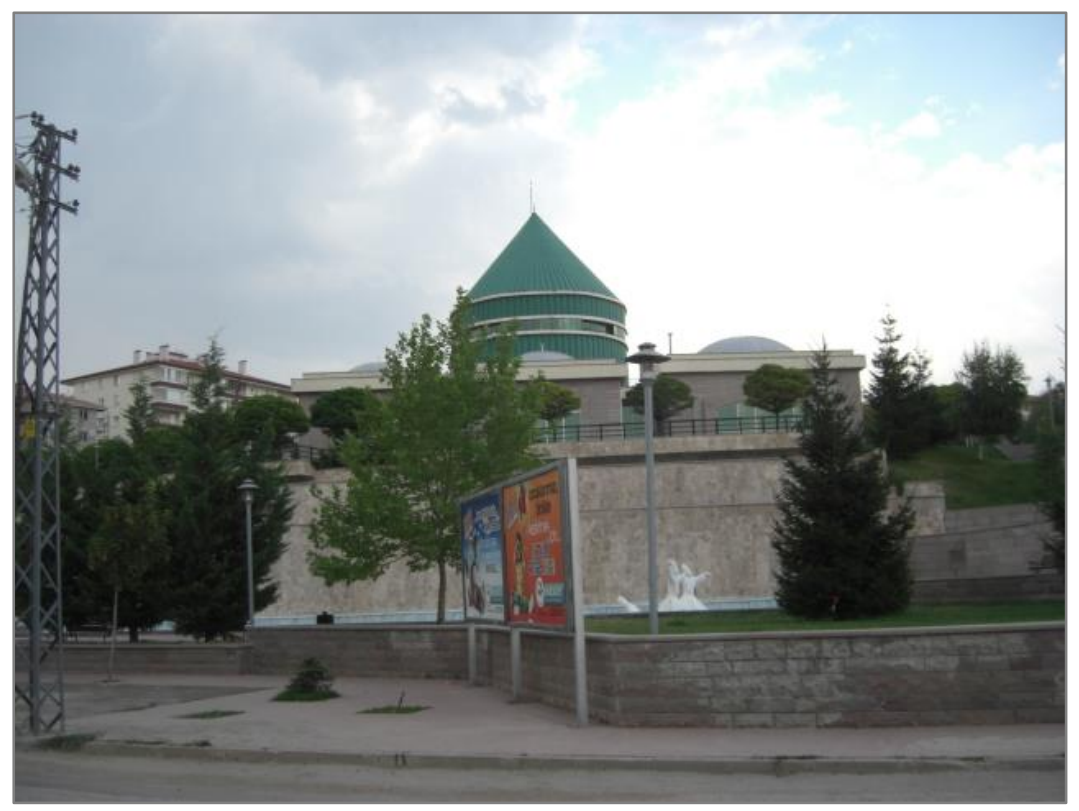

Figure 4 The Women Social Activity Centre in the Mevlana/Rumi Park in Baspinar Neighbourhood. Akyuz (2016) 
Another service provided by the municipality is free domestic trips to historical places of Turkey, such as Çanakkale (Troy), Konya Mevlana/Rumi Museum. The trips, organised and paid for by the municipality, are only open to women who live in neighbourhoods nearby. Each trip is organised for 45 people and if there is too much demand then participants draw lots. During the trips, all the participants receive accommodation in 4-5 stars hotels. All of these expenses, including travel and accommodation, are paid by the municipality. Municipal funding stems from a variety of sources, such as donations and municipality activity funds (Official 1 ). There are also youth social centres in Altindag. Similarly, the youth centres have courses such as guitar, violin, theatre, chess and Turkish Folk Dance. There are also facilities for wrestling, table tennis, boxing, archery and so on (Interview 13). The programs of the courses are designed based on demand from the neighbourhoods.

The improvement of the services in the neighbourhood was raised many times in the interviews. I would suggest, therefore, that the main difference between the contemporary period and the past was a general neglect of these peripheral locations for decades. Generally, people think the social services such as schools, hospitals, health centres and parks are good enough now.

\subsection{Losing Social Connections}

Although the redevelopment provides improved infrastructure and urban services, the quality of the buildings varies based on the private developers. Some gecekondu owners complained about the quality of the construction materials of the new flats. Interviewee 10 suggests that:

'The developers use lower-quality materials than they are supposed to use. ...We don't trust the developers, they don't respect us. I received a loan with a high-interest rate, I am struggling to pay it, and 10 years is a very long time. The houses are our biggest and only asset. However, even before the first-year finishes, there is a problem with the plumbing; there is no storage in the building. They [the developers] had to make storage units in the building; I don't know how they found a way to bypass that regulation.

Furthermore, the lack of sound and heating insulation in the apartments also creates further conflict amongst the residents. The gecekondu owners have lived for decades in separate houses. As such, it is not easy for them to adapt to the conditions of apartment life. There are many arguments in apartments about sounds from neighbours. Interviewee 7 is the apartment manager and says, 'I have lived in this building for 3.5 years. If I don't yell at people, they don't listen to me. These people get used to the gecekondu life. Here, we live as a community, they have to respect that. This is apartment life; they have to accept the rules.

Even though the neighbours stay in the same neighbourhood the self-produced space gets lost as a result of the redevelopment projects and alongside the space the previous social connections. In gecekondu, residents had an active social life in the gardens and in the houses; the reconstruction demolishes this daily life as well. Despite the material development, such as hot water and heating, the new daily life has been described as very monotonous and boring by nearly all participants. Interviewee 12 explains: 'The gardens and social life in the gardens were very relaxing; it was a hobby and an activity for us. On the weekends we used to have barbeques. We lost those connections, now I had to go $20 \mathrm{~km}$ for a barbeque. How can we do that? If you try in the balcony they complain to the building manager.'

\subsection{Fragmentation and Atomisation}

The long process of negotiation between neighbours and developers creates conflict between neighbours. Many neighbours argued with each other and sometimes it ended in litigation. There was formal land ownership and homeownership before, so whilst ownership is not a new concept, the increasing ground rent and individual legal agreements atomised the gecekondu owners. These conflicts, before and during the redevelopment about reaching an agreement, weaken bonds of solidarity. Individual property ownership logics then make residents work more for their own interests rather than as a collective. One of the main drivers of conflict relates to the gain of the 
other gecekondu owners. People were suing their neighbours in order to get more money for their land. The redevelopment atomises and individualises the gecekondu owners. Firstly, during the negotiation process individual ownership rights (land titles) damage the solidarity and neighbours negotiate and compete to maximise their return.

Secondly, the apartments/flats and the reconstruction of the built environment makes people more individualistic/atomised in daily life and alienated in social relationships. The redevelopment achieves this by deconstructing the social networks and the gecekondu space. There is a common opinion about the loss of neighbourhood relationships as a result of redevelopment. A Participant explained, in the hometown association, 'in the apartments you don't have the previous relationships with neighbours. People live in different conditions and places now. Everybody focuses on their family now; we cannot visit people as we did before. It is not the same as in gecekondu anyway; we were neighbours for 30-40 years in gecekondus.' The formal space of redevelopment destroys the active and productive use of green spaces. Even though the green space has increased in quantity, people don't feel the parks and the green space are very useful. Interviewee 12 says, 'the flats do not fit the traditional Turkish lifestyle. The apartments make us lose the traditional lifestyle. We used to do gardening with our neighbours and chat every so often'. In comparison, it was very common for people to describe flats as "modern prisons", "luxury prisons", "high prisons", and "cages".

The experiences of the gecekondu owners who moved to new apartments are very different to classic examples of gentrification, but it is not a wholly positive process. In short, living in an apartment increased the material quality of living conditions for the former gecekondu residents. Not only the housing conditions but also the urban facilities and economic activities in the neighbourhoods increased with the redevelopment projects. However, there are problems with the IDP redevelopments. The quality of houses varies based on the small-scale developers and living costs increased. New flats have heat and sound insulation problems. The previous social structure and life gets lost in the new flats. The gecekondu resident fragment during the negotiation process, based on private ownership rights. The combination of fragmentation and the monotonous nature of apartment life, then, create further atomisation of working-class people in the Altindag case.

\subsection{Economic benefits of redevelopment projects for gecekondu residents}

The benefits and disadvantages of the programme varied sharply between different groups of residents. While for gecekondu owners there are many economic benefits, there are also many disadvantages. For the disadvantages of redevelopment projects for gecekondu owners.

The first and the biggest benefit of the redevelopment for gecekondu owners are the flats given for their land. Gecekondus are self-produced spaces and there are strong neighbourhood relationships. As we have seen, however, the standards of life in gecekondu are very low and the infrastructure is not adequate. Therefore, with the redevelopment, the gecekondu owners take advantage of state and private sector investment in the neighbourhood. Although the situation changes based on each construction, on average owners of $150 \mathrm{~m}^{2}$ of land get a free house. The first group of people in the legal landowners with $150 \mathrm{~m}^{2}$ and above land. They can get at least one flat as a result of the redevelopment. This group is shown in green in Figure 5 . The second group of people are without any legal title. In this condition, even if they occupied a large amount of land, historically they could not get any discount or house. They can buy the houses from the developers as any ordinary home buyer. The third group of people live in the gecekondu preservation area in the Baspinar neighbourhood. The Altındağ Municipality takes the initiative for these redevelopments and sells them the land they have occupied since the 1970s. They paid 15,00020,000 Liras. In this, the municipality subsidises a total of 1383 gecekondu residents. Gecekondu preservation areas were land given to low-income groups in order to prevent illegal gecekondu construction. These people could not have a title to the land but built their houses and occupy the land. 
The fourth group of people are the people without any land ownership. These include tenants and anyone who could not get the legal titles of the houses because of different reasons. For these groups of people, the only possibility is buying houses through private credit or MHA credit. Since the zero-tolerance of gecekondus policies and lack of available land, the only possibility is homelessness or temporary slums.

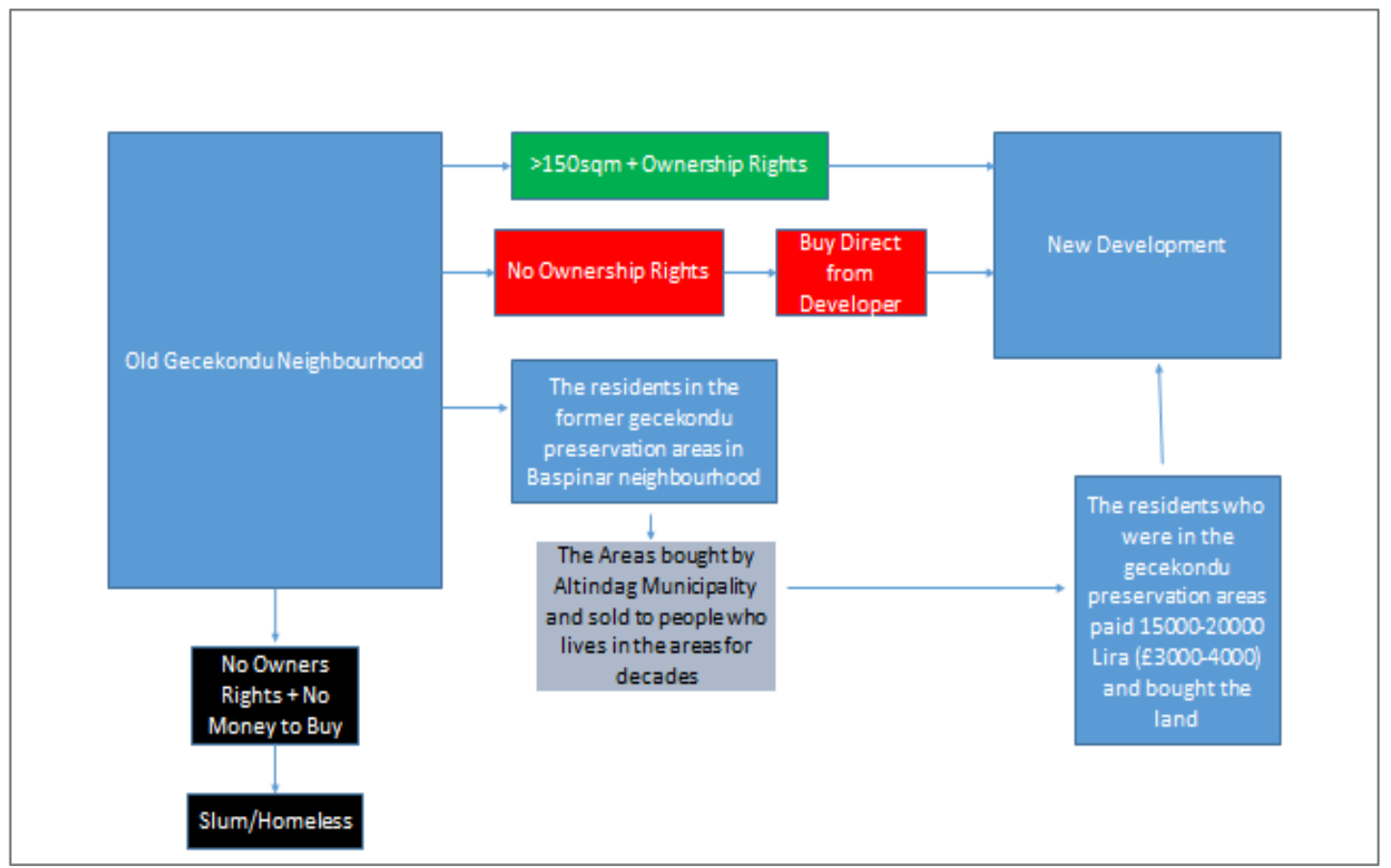

Figure 5 Clearance of land ownership pattern for redevelopment by Municipality. Source: Sinan Akyuz, illustrated from interviews and municipality report, 2016

Another advantage of redevelopment for those who are staying in the area is that it increases urban and public service provision in the neighbourhood. For example, there was not any post office or bank in the neighbourhood before. The number of schools was much lower than currently and there were not any social facilities such as the women's and youth centres. These services and many shops have opened in the area with the increasing population.

The recent Disaster Act is providing 18 months of rent subsidies to gecekondu owners. Therefore, rent during the construction period is subsidised by central government. This act worked as an important catalyst in redevelopment as a result of up-scaling the state intervention to the built environment.

\section{Conclusion}

The provision of low-income housing and providing basic urban services has been always problematic in Turkey. Due to inadequate housing supply migrants built their gecekondus. The migrants not only built their gecekondus, but they also built a social life and support mechanisms within the neighbourhood. Although having these positive features gecekondu, for many dwellers, meant a lack of material comfort, inadequate infrastructure and poverty. The inadequate infrastructure and the lack of material conditions for human dignity saw people suffer for decades in gecekondu houses. Although the government legalised the gecekondus and provided basic services, such as water and electricity, the absence of conditions for modern human standards continued.

After the restructuring of the banking system in 2002, the city restructuring programs entered a new stage. Due to the upward-scaling of the state intervention in the built environment post-2002, we have witnessed a dramatic increase in investment in infrastructure and mega projects from both 
central and local governments. Higher capital and administrative power allowed intervention in previously non-intervened areas such as Altindag. Therefore, it was possible to redevelop these areas after 2002.

Gecekondu housing is outside of normal capitalist relations of land ownership and building. The elimination of the gecekondus was partly aimed at subjecting low-income residents to the rule of money and law. Since the 1980s workers in employment have been subjected to greatly increased disciplinary power of capital and the state. However, governments since 2000, have also cooperated with at least a portion of the urban working class by providing a higher material standard of housing combined with new social and cultural facilities in the neighbourhoods.

Although providing basic services and housing for titleholders, the major problem with the redevelopment is a formalisation of housing provision that excludes tenants and people without a title for their informal houses. As a result, the people without title deeds have to live in even worse conditions than before. Conditions they share with new migrants, without formal employment relationships who are also excluded as a result of the redevelopment.

The redevelopment projects, on the one hand, provide better housing conditions for established migrants and the urban poor, on the other hand, they take away the opportunities that the previous migrants had in being able to access such as cheap housing. The only route to cheap housing after these projects is the formal private and state credit systems. In this way, redevelopment integrates the urban poor into the formal credit system or totally excludes them from social and economic life, as in the case of recent rural-urban migrants.

\section{References}

Akbulut, M. R. and Başlik, S. (2011) 'Transformation of Perception of the gecekondu Phenomenon.', METU Journal of the Faculty of Architecture, 28(2).

Akyuz, S., 2018. Redevelopment of the squatter settlement Neighbourhoods in Ankara, Turkey (Doctoral dissertation, University of Sheffield).

Ankara Metropolitan Municipality (2005), 2025 Nazım Imar Planı Raporu, Ankara, Turkey.

Bayırbağ, M. K. and Penpecioğlu, M. (2015) 'Urban crisis: “Limits to governance of alienation”', Urban Studies. SAGE Publications Ltd, 54(9), pp. 2056-2071. doi: 10.1177/0042098015617079.

Brenner, N. (1999) 'Globalisation as reterritorialisation: The re-scaling of urban governance in the European Union', Urban Studies, 36(3), pp. 431-451. doi: 10.1080/0042098993466.

Brenner, N. (2004) 'Urban governance and the production of new state spaces in Western Europe, 19602000', Review of international political economy. Taylor \& Francis, 11(3), pp. 447-488.

Cox, K. R. (2009) “"Rescaling the state"in question', Cambridge Journal of Regions, Economy and Society. Oxford University Press, 2(1), pp. 107-121.

Clarke, S. (1991a) 'Marxism, sociology and Poulantzas's theory of the state', in the state debate. Springer.

Çelikkan, Erdinç, (2011) 'Kentsel dönüşüme 400 milyar dolar gidecek, 'afet hesabı' açılacak', Hürriyet, 14 Kasım, viewed 15 June 2016.

https://www.hurriyet.com.tr/ekonomi/kentsel-donusume-400-milyar-dolar-gidecek-afet-hesabi-acilacak19235425

Das, R. and Gough, J. (2016) 'Jamie Gough Sheffield University', Human Geography Specıalıssue: Marxist Geography Jamie Gough Sheffield University, England, 9(3).

Dündar, Ö. (2001b) 'Models of Urban Transformation', Cities, 18(6), pp. 391-401. doi: 10.1016/S02642751(01)00031-2.

Elicin, Y. (2014) 'Neoliberal transformation of the Turkish city through the Urban Transformation Act', Habitat International. Elsevier Ltd, 41, pp. 150-155. doi: 10.1016/j.habitatint.2013.07.006.

Geray, C. (2009) 'Toplumsal Konut Yöneltisi ve TOKi'nin Tutum ve Yöneltilerindeki Son Değişiklikler', içinde Kent ve Planlama-Geçmişi Korumak Geleceği Tasarlamak.

Gündoğdu, I. and Gough, J. (2009) 'Class cleansing in Istanbul's world-city project', L. Porter and veK Shaw (eds.) Whose Urban Renaissance.

Güzey, Ö. (2009) 'Urban regeneration and increased competitive power: Ankara in an era of globalization', Cities. Elsevier Ltd, 26(1), pp. 27-37. doi: 10.1016/j.cities.2008.11.006.

Güzey, Ö. (2016) 'The last round in restructuring the city: Urban regeneration becomes a state policy of 
disaster prevention in Turkey', Cities. Elsevier B.V., 50, pp. 40-53. doi: 10.1016/j.cities.2015.08.010. Jessop, B., 1990. State theory: Putting the capitalist state in its place.

Jones, M. R. (1997) 'Spatial selectivity of the state? The regulationist enigma and local struggles over economic governance', Environment and Planning A. SAGE Publications Sage UK: London, England, 29(5), pp. 831-864.

Keleş, R. (2014) 100 Soruda Türkiye'de Kentleşme, Konut ve Gecekondu. Cem Yayınevi.

Page| 365 Koksal, R. (2012) 'Altındağ' da Kentsel Dönüşüm', in. Trabzon: Türk Dünyası Mühendislik, Mimarlık ve Şehircilik Kurultayı,.

Yılmaz, E. (2016) 'Konut Sorunu Ve Toplu Konut Üretiminde Toki’nin Ve Belediyelerin Rolü’

\section{Resume}

My name is Sinan Akyuz and I am a lecturer at Abdullah Gül University. After studying Town and Regional Planning at Ankara Gazi University, I worked in the private sector as an urban planner for a year. Afterwards, I studied MSc in International Planning and Development at Cardiff University. I had my PhD in the University of Sheffield in the Urban Studies Department, and the title of my thesis is "Redevelopment of squatter settlements in Ankara, Turkey" and finished in January 2019. Currently, I work at Abdullah Gül University in the Architecture Department as Lecturer. In harmony with the UN 2030 Agenda for Sustainable Development Goal 11 which focuses on making cities and human settlements inclusive safe resilient and sustainable, my current research agenda focuses on urban redevelopment projects through integrating the finance sector into housing and the effects of these projects on the historical squatter settlements neighbourhoods in Ankara, Turkey. 